\title{
Preconditions of Digital Violence at PRimary SCHOOLS
}

\author{
LJUbojeV, N, GlusaC, D \& RAdosav, D.
}

\begin{abstract}
The use of the Internet provides many opportunities for the psychosocial development of pupils: from communication, entertainment, to acquiring the skills of digital, information and critical literacy, essential for life in the $21^{\text {st }}$ century. However, the results of the survey show that children on the Internet, besides positive ones, also experience different negative experiences and digital violence.The authors of this paper are analyzing the digital violence relevantfor the protection of children as Internet users in the Republic of Serbia. A survey among the pupils of one primary school in the Autonomous Province of Vojvodina, in the Republic of Serbia, was carried out. Accordingly, interdisciplinary research including pupils' perception ofdigital violence and protection on the Internet.The conducted research has confirmed the hypothesis that there are prerequisites for digital violence in elementary schools.
\end{abstract}

Key words: protection of students, digital violence, Internet, Republic of Serbia.
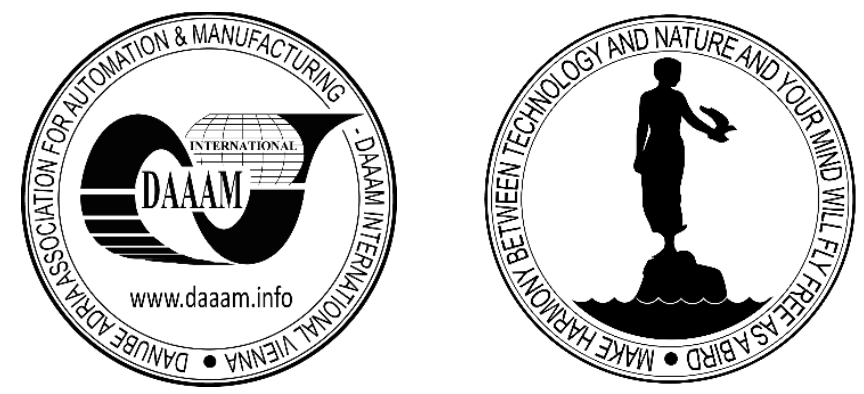

Authors' data: Assoc. Prof.Ljubojev, N[adezda]*; Full Prof.Glusac, D[ragana],* Full Prof.Radosav, D[ragica],* *University ofNovi Sad, Technical Faculty "Mihajlo Pupin" Zrenjanin, DjureDjakovica bb, Republic of Serbia, nadezdaljubojev@gmail.com,glusacdragana.zr@gmail.com,dolores023@open.teleko m.rs.

This publication has to be referred as: Ljubojev, N[adezda]; Glusac, D[ragana] \& Radosav, D[ragica] (2019). Preconditions of Digital Violence at Primary Schools, Chapter 01 in DAAAM International Scientific Book 2019, pp.001-016, B. Katalinic (Ed.), Published by DAAAM International, ISBN 978-3-902734-24-2, ISSN 17269687, Vienna, Austria

DOI: $10.2507 /$ daaam.scibook.2019.01 
Ljubojev, N.; Glusac, D. \& Radosav, D.: Preconditions of Digital Violence at Prima...

\section{Introduction}

Today there is a rapid increase in the number of users of digital technology and the Internet, especially among children and young people. Mostly, social networks and the Internet bring many benefits for children. For example, they can be used in education, as a teaching tool or context (a virtual classroom) (Munoz \& Towner, 2009; Pardanjac, et al., 2014; Glusac, et al., 2015). In addition to providing numerous opportunities for learning and development, modern technology supplies young people with the entire arsenal of tools for social cruelty (Shariff, 2008).

The prevalence of the use of digital media is high, because the fact that digital technology permeates everyday life of people around the world, and digital media has become the most widespread media. For generations born and growing up in the digital age, digital communication is a common and even dominant form of communication. Among Internet users, globally, there is approximately one-third of those under the age of 18 (Livingstone, et al., $2016 \mathrm{~b}$ ).

The use of digital technologies involves an increasing number of people at a younger age. "Youth (age 15-24) is the most connected age group. Worldwide, 71\% are online compared with $48 \%$ of the total population. African youth are the least connected "(UNICEF, 2017). Studies in the United States show that two-thirds of children under the age of 11 have a computer with the Internet in their household, that children aged 5-9 years spend on average half an hour online a day; $31 \%$ of children aged 8-10 have their own mobile phone (Gutnick, et al., 2010).

In Europe, it is estimated that $86 \%$ of Norwegians, $71 \%$ of Britons, $67 \%$ of Germans are connected to the Internet. Among children aged 6-10 years, the internet users in Finland make 88\%, Sweden 77\%, Romania 57\%, Germany 56\%, Italy 34\% (Livingstone, 2009).

According to UNICEF estimates, one-third of Internet users globally are children, with the proportion of Internet users likely to be higher in lower-income countries where the Internet is rapidly permeating all spheres of public life (Livingstone, 2017).

Statistical data for the Republic of Serbia indicate that the presence of a computer in households has increased from $55.2 \%$ to $64.4 \%$ in the period from 2012 to 2015. In the same period, the penetration of the Internet in households was even more intense (from $47.5 \%$ to $63.8 \%$ ), while in mobile phones, the situation in the Republic of Serbia is within theframework of European trends (85.8\% in 2012, 91.4\% in 2015) (Republic Institute for Statistics, 2015). Dramatic growth is evident if the data is compared with the results of previous surveys in the Republic of Serbia, which tell about the growth of Internet users in the Republic of Serbia: according to the Internet World Stats in 2002, there were 6.1\% of Internet users in Serbia and Montenegro (Golcevski \& Milovanovic, 2004).

The most popular social networking sites on the Internet are Facebook, Instagram, and Snapchat, and most students use several social networks, a trend that is also registered in some other environments (Lenhart, 2015). At the end of 2013, the profile on some of the social networks (mostly on Facebook) had 89\% of elementary students and $92 \%$ of high school students from the Republic of Serbia. 
This survey found that students most often use the Internet to visit social networks $(69 \%$ of elderly students and $81 \%$ of high school students daily or almost daily), then to watch videos, series and films (daily or almost daily $50 \%$ of elders and $62 \%$ of high school students), and surf the Internet (35\% of elderly students and $49 \%$ of high school students daily or almost daily).The majority of students in the 4th grade of the elementary school use the Internet for playing games (95\% of students), while the second place occupies watching spots, series, films ( $85 \%$ of pupils). Also, it has been found that the least represented activities on the Internet are: reading and writing blogs, visiting the forums and exchanging e-mails (Popadic \& Kuzmanovic, 2013). Another research shows that younger children use the Internet for entertainment (playing games, listening to music, watching videos, series,and movies), while older ones mostly use social networks (Stevanovic, et al., 2014).

With the increasing availability of digital technologies and the increasing involvement of children in the world of communications and the Internet, the risks of their potential exposure to various inappropriate content (sexual, pornographic, violent), manipulation, abuse and exploitation grow.

While research on digital violence is very presentin the world, especially in the last two decades, there are still a fewtypes of research on this subject. The data collected in the research on this subject can have a great impact on the perception of the individual and social significance of this issue. Particularly important is the insight into whether there are prerequisites for digital violence in elementary schools. In this regard, the data from the research, within the master's thesis, include the sample of 83 children of school age aged 11-15 in the Autonomous Province of Vojvodina (APV), in the Republic of Serbia (Coric, 2018). The views on the risks and attitudes regarding the safety of children on the Internet were examined.

\section{Risks in Cyberspace}

By enacting the Law on the Ratification of the UN Convention on the Rights of the Child, Republic of Serbia committed itself to take measures to prevent and ensure the protection of children from all forms of domestic violence, institutions, and the broader social environment.The Convention on the Rights of the Childis the first international legal document that contains the catalog of all the children's rights. Article 1 of the CRC defines "child" as any person "below the age of eighteen unless, under the law applicable to the child, the majority is attained earlier". Importantly, the Convention on the Rights of the Child leaves open the option for States to adopt lower or higher ages of majority, thus giving state parties some leeway in defining childhood. Convention on the Rights of the Child prescribes all member states are bound to protect the child from all forms of sexual exploitation and sexual abuse (Art. 34 Convention on the Rights of the Child). The Republic of Serbia is a signatory to two European Council conventions: Convention on Cybercrime (adopted in Budapest in 2001) and Convention on Protection of Children against Sexual Exploitation and Sexual Abuse (Lanzarote Convention). 
Ljubojev, N.; Glusac, D. \& Radosav, D.: Preconditions of Digital Violence at Prima...

Through digital technology, perpetrators can access the victim at any time and from any place, and the victim can become a permanent target of victimization. The most important specificities of digital violence in relation to the classical forms of violence are a high degree of anonymity of the perpetrators, the constant availability of the victim, the infinite audience and the durability of the act. Anonymity encourages abusers but increases the insecurity of the victim (Popadic \& Kuzmanović, 2013). The anonymity provided by many online platforms is widely held to facilitate "disinhibition and deindividuation" (Kowalski, et al., 2014; Livingstone, et al., 2016a). Perpetrators feel able to act aggressively online in ways they would not when face-to-face with potentialvictims, because the social norms that constrain them areweaker when they cannot be identified and because theycannot see the emotional effect on their victim (Kubiszewski, et al., 2015; Livingstone, et al., 2016a).

The authors Popadic and Kuzmanovic point out that the number of persons involved in violent incidents is difficult to control, information can be permanently preserved and once placed they become hard to destroy. The specificity of digital violence can also be accounted for by the fact that it also possesses the ability to use electronic technology (which does not necessarily apply to the victim), and that, in view of (un) publicity of these procedures, the supervision of adults is minimal (Popadic, et al., 2016).

Digital violence includes all the cases when someone uses electronic devices ( $a$ computer, a mobile phone, etc.) to deliberately intimidate, insult or humiliate the other.Digital technologies are often used by adults who falsely present themselves and communicate with young people for the purpose of sexual abuse. Therefore, there has been more and more talk about sexual abuse online (Bogavac \& Otasevic, 2015). The Internet provides various ways of sexual abuse (through social networks, companies). Sexual predators on the Internet do not have a clear profile, their professions and age vary, although research shows that these are the most commonly men (Wolak, et al., 2008).

Scientists, practitioners, but also the general public, increasingly discuss violence among children and youth, about cyberbullying. The usual term for denoting this form of violence is cyberbullying.

In theory, according to the definition of classical bullying as a deliberate harm (physical and psychological) to the other, where the injury is repeated and there is disproportionate power between the perpetrator and the victim, the cyberbullying is considered to be such a violation by using electronic devices (mobile phone, computers, etc.) (Popadic \& Kuzmanovic, 2013; Livingstone, et al., 2016a). According to this definition, digital aggression excludes one-off aggressive practices and aggressive actions where there is no difference in power. Some authors consider that there are many convincing reasons why those who deal with violence should not be limited to dealing only with repeated cases of violence (Popadic \& Kuzmanovic, 2016). Bullying among children, the repeated physical, verbal or symbolic aggression intentionally expressed by one or more peers towards a less powerful victim - is understood in somewhat different ways in different cultures, and thus terminology and definitions vary (Chester, et al., 2015; Livingstone, et al., 2016a). 
In the US, it has been argued that bullying is a form of harassment (Wright, 2014). In the UK it is strongly associated with the school, but in Germany, the word 'mobbing' derives from the workplace (Livingstone, et al., (Eds.), 2012; Livingstone, et al., 2016a)

Bullying in schools is a prevalent problem and can have serious physical, mental, social, and behavioral short and long-term consequences for those involved (Eslea, et al.,2004; Bauman, et al.,2013; Kowalski, et al.,2014; Wachs, et al., 2018). Bullying is defined as any repeatedly aggressive behavior against persons or groups that cannot readily defend themselves (Olweus, 2012). Bullying may involve physical assault, such as hitting or kicking, verbal harassment, such as hurtful name-calling, verbal threats, and verbal abuse, as well as selectively undermining social relationships through manipulation or exclusion from social groups (Solberg \&Olweus, 2003; Wachs, et al., 2018).

Estimates of incidence, although using standardized definitions and measurement across 42 European countries, the Health Behaviour in School Children (HBSC) survey reported an average of $11 \%$ of 11-15-year-olds have been bullied at school at least two or three times in the past couple of months.)(Inchley, et al., 2016) (Eds.); Livingstone, et al., 2016a)

When it comes to the category of the risky contact, it is important to point out that cyberbullying, i.e. harassment and bullying on the Internet deserves special attention because of negative consequences it has on individuals, their emotional and social functioning.

Cyberbullying is the use of digital technology with the aim of disturbing, harassing, humiliating and harming another person. Usually it happens among peers, however, there are not rare cases when adults are violent towards children and young people on the Internet. In these cases, it is most often a matter of harassment or stalking over the Internet.

In terms of victims, research suggests that both offlineand online, victims are more likely to come from minorityethnic or LGBT groups, to be disabled or facing mentalhealth, emotional or familial difficulties (Baek \& Bullock, 2014).

Based on the knowledge of experts in this field, it is the fact that this type of bullying can also happen in contact with peers and school friends and that is why it is harder to control this type of risk on the Internet by using Internet filters. According to the official statistics of the National Crime Prevention Council (NCPC), half of the American teenagers are victims of cyberbullying, while the research also shows that $81 \%$ of them consider it amusing (NCPC, 2010). Therefore, representatives of the European Commission and 17 social networks (including Facebook, Myspace, etc.) signed a contract according to which they will protect children from cyberbullying and violence on the Internet alltogether (Ruzic, 2011).This measure is understandable because cyberbullying is happening often via social networks.

Based on the research carried out by the Provincial Ombudsman, data were receivedfrom the police departments in APV, i.e. from the police stations on their territory, about the number of reported, denied and processed cases during 2011 and 2012. The data shows that two cases of child exploitation on the Internet were reported on the territory of the police department Zrenjanin. 
Ljubojev, N.; Glusac, D. \& Radosav, D.: Preconditions of Digital Violence at Prima...

One case was about cyberbullying, wherein perpetrators were children and the other case referred to sexting (Exploitation of Children on the Internet: Research Report of the Provincial Ombudsman).

In a relatively short period, the Internet has become the most popular media among children. They gain excellent information technologies knowledge at an early age and because of that, they are prone to the influence of this digital media. It is also troubling that children Internet users entrust their personal information to strangers. According to the research, even $31.1 \%$ of boys and $27 \%$ of girls aged from 9 to 15 , point out that they shared their personal data on the Internet (e-mail address, phone number, and even their home address)(Dowell, et al., 2009). A potential consequence of revealing personal information on the Internet can lead to unwanted contacts out of the network, which can bring a child into physical danger. Some authors point out that it is not empirically confirmed that the leaving of personal data is directly related to the risk of victimization, but other risky behaviors are usually included (Ybarra, et al., 2007).

The ability of children to work on a computer is an important factor in maintaining security on the Internet. This applies in particular to the knowledge of the procedures for protecting privacy and the risks they may be exposed to on the Internet. Research in Europe shows that digital competence is better at an older age, that boys are slightly more competent (Livingstone, et al, 2011). This study shows that the most competent children are from Finland, Slovenia, the Netherlands, and Estonia. However, along with the improvement of competencies, with the experience and time spent on the network, the awareness of the users that their capacity to protect against potential threats is also threatened (Livingston \& Brake, 2010).

\section{Research on Digital Violence in the Republic of Serbia}

One of the recent research in the Republic of Serbia is the research of the Ministry of Education, Science, and Technological Development, UNICEF and Telenor. The research is part of the project "Stop the Digital Violence" launched under the program "School Without Violence - Towards a Safe and Encouraging Environment for Children".

The survey was carried out in 2012, in 17 elementary and 17 high schools from the territory of the Republic of Serbia (the sample was stratified by region, type of school and size of the city). The survey conducted was a survey type. A total of 3,786 students were examined (2272 from elementary and 1514 from high schools) (Popadic \& Kuzmanovic, 2013).

The results of this research (Popadic \& Kuzmanovic, 2013) show that the use of digital devices and the Internet is very widespread among students from the Republic of Serbia, as well as that the availability and frequency of use increase with the age of students. The data show that while in the fourth grade of elementary school $84 \%$ of students have a mobile phone, at the elementary school age $94 \%$ of students have mobile phones, while in secondary school there is only $1 \%$ of those who do not have it. Over $90 \%$ of students in this survey use a computer, while $60 \%$ have their own computer. 
Among the students interviewed, the Internet is not used by $17 \%$ of students in the 4th grade, $6.5 \%$ of the older students and $3 \%$ of high school students.

The authors Popadic \& Kuzmanovic have found that there are no significant differences in the use of the Internet between boys and girls, at any age. In addition, at the youngest age, children from smaller towns use the Internet less frequently than children from larger towns, but at an olderage, this difference is lost. In doing so, these authors concluded that in this case the Internet does not create a "digital gap" among children from smaller and larger places, but level differences in the context of growing up as a result of the size of the site.

In addition, in this survey data showed that when it comes to students' exposure to online risks, $62 \%$ of senior students and $84 \%$ of high school students in the past year have been at least once exposed to one of the risks on the Internet. The basic forms of risky behavior were: sharing of personal data, communications (messages or notes) and meetings with strangers.

Thus, the most common risky behavior in both age groups was the acceptance of a friendship request on social networks from unknown people (43\% of elderly and $71 \%$ of high school students). More than a quarter of elementary school seniors (28\%) and more than half of high school students (56\%) said in the survey that once or more times in the past year they communicated through a chat line with unknown people, and some also accepted meetings with people they met via the Internet $(6 \%$ of primary school students and $15 \%$ of high school students).

Among the examined students, significantly less (between $10 \%$ and $15 \%$ ) of those who stated that they exposed their peers to some type of risk on the Internet (such pupils are somewhat more among primary school students than among high school students). The data show that the most common was about concealing identity in communication via the Internet, opening and using someone else's account or profile on a social network without the owner's consent, putting pictures or recordings and offensive comments (Popadic \& Kuzmanovic, 2013).

Research conducted by Popadic \& Kuzmanovic, 2013, showed that as the age of using digital devices increases, the frequency of risky behavior increases, the frequency of digital violence and the number of students involved in it are also increasing, with online threats increasingly dominating over the endangering calls and SMS messages via mobile phone. Data showed that in the past year, one-fifth of students in the 4th grade of elementary schools were at least once exposed to digital violence (19\% experienced violence via mobile phones and $12 \%$ were online via internet). One-third of elementary school seniors have experienced some form of digital violence at least once (32\% over a mobile phone and $39 \%$ over the Internet). However, half of the total number of students who have experienced digital harassment is declaring that such behavior did not disturb them at all. Therefore, the authors Popadic \& Kuzmanovic emphasize that pupils tend to interpret some of their peers' behavior as meaningless, friendly teasing, joking, and not as malicious damage or injury. In most cases, students know who harasses them - these are the largest number of their peers, but almost the same from their school and those who do not go to their school (Popadic \& Kuzmanovic, 2013). 
Ljubojev, N.; Glusac, D. \& Radosav, D.: Preconditions of Digital Violence at Prima...

Research shows that taking into account the connection between digital violence and typical forms of school violence, undertaking systematic preventive measures to reduce typical forms of peer violence would also contribute to the reduction of digital violence (Popadic \& Kuzmanovic, 2016).

In the Republic of Serbia, research is mostly focused not on digital, but on typical forms of school violence. Results research (Sokolovska, et al., 2015) showed that verbal violence forms were the most dominant in peer violence and victimization interactions, which is in line with previous research. This form includes aggressive behaviors such as harsh jokes or making fun of someone, insulting others and being abusive to someone. This study aimed at examining different forms of violence and victimization among high school students from the urban area, including relevant factors such as testing period, gender, grade, and school achievement. The sample included 947 high school students out of which 489 were examined in 2013 and 458 in 2014. Students were from the second, the third and the fourth grade of different high schools from the city of Novi Sad (Republic of Serbia). Peer Violence and Victimization Questionnaire (PVVQ) that contains questions about different forms of physical, verbal, and relational violence and victimization in the last school year (Sokolovska, et al., 2015) measured peer violence and victimization. This result is in line with previous research in our country, according to which verbal violence is the dominant form of violence among students at primary and secondary schools (GasicPavisic, 2004; Kodzopeljic, et al., 2010; Pavlovic\&Zunic-Pavlovic, 2008). Relational violence is expressed in lesser percent, and in the least physical violence, but certainly worrying when compared to the rough standards of incidence of violence in other countries. The fact is that the increase was recorded in younger students. Some authors believe that moving to secondary school and changing the school environment is often a critical period for exposure to violence (Pellegrini \& Long, 2002). It is also believed that it is possible that the stressful period that marks the adjustment to the new environment, with life in the urban environment and the current social situation, makes younger students more resorting to violence in response to these changes (Sokolovska, et al., 2015).

The school has an indisputable role in the prevention and resolving of the problem of digital violence. Some authors believe that students should be informed about what is considered digital violence and that it, like other forms of violence in school, will not be tolerated. It is necessary to systematically work on sensitizing students and developing awareness about the negative consequences of digital media abuse. Therefore, information on the positive and negative aspects of using the Internet, potential risks and ways to safely use digital media must be made available to all students and teachers, as well as to parents (Glusac, et al., 2017). The fact is that children are often larger experts than their parents in this field (Glusac, et al., 2015).

Research shows that a significant number of parents have expressed their fear that children might come into contact with strangers, but no parent has expressed concern about unpleasant and disturbing contacts with Internet users their children know (Zukovic \& Slijepcevic, 2015). 
This refers to peer violence, which increasingly appears on the Internet, which involves sending threatening or abusive messages, spreading false information about someone, unauthorized entry to someone's profile and changing a password, and the like. The spread of this type of risk is confirmed by research findings in the United Kingdom (Livingstone \& Bober, 2004), which was conducted on a sample of 1511 students aged 9-19 years. The survey found that 33\% of students reported being harassed by their peers via the Internet or SMS.

However, this research included 906 parents of the students. The research has shown that parents underestimate the negative experience of their children on the Internet, and are often unaware that children need help. The biggest differences were noted in relation between parents and children to cyberbullying, as 33\% of children were reported being victims, while only $4 \%$ of parents reported that they knew their children had experienced it (Livingstone \& Bober, 2004, according to Zukovic \&Slijepcevic, 2015).

Therefore, the Serbian legislation should continue to regulate the protection of children on the Internet as vulnerable groups in the new security area. It is also important to include the protection of children on the Internet in the future Strategy on the Development of Information Security of the Republic of Serbia, which would lead to the strengthening of the legal framework and capacities of institutions dealing with children (Ljubojev, et al., 2017).

By amending the 2003 Criminal Code, using a computer network or communication with other technical means for the commission of criminal offenses against sexual freedom against a minor (Article $185 \mathrm{~b}$ ) is defined as a criminal offense punishable by law.

Cyberbullying, characteristic for more frequent peer violence through digital technology among children, is not recognized in any way as an individual type of violence against children through digital technology. These types of electronic violence are important in legal regulation for two reasons: so that systematic information and education of children and their prevention can be done, but also that their direct and indirect victims could be provided with adequate assistance and protection (Glusac et al., 2017).

The shift was made by the adoption of the Decree on the Safety of Children in the use of information communication technologies, on the basis of which the National Contact Center for the Safety of Children on the Internet was established. For the first time in the Republic of Serbia, this Decree regulates preventive measures for the safety and protection of children in the use of information communication technologies and treatment in case of violating or endangering the safety of children on the Internet (Ljubojev, et al., 2018).

With the aim of preventing and protecting from violence against children through digital technologies, it is necessary to improve the existing legal framework and implement positive obligations of the Republic of Serbia from the accepted international agreements that the Republic of Serbia has entered into. The legal system of the Republic of Serbia should be further harmonized with the EU acquis in this area. 
Ljubojev, N.; Glusac, D. \& Radosav, D.: Preconditions of Digital Violence at Prima...

\section{Research and Research Results}

\subsection{The Subject of Research}

As digital communication is an almost everyday form of communication between today's pupils and students, it is important to understand the ways in which, and under what conditions, digital violence can leave serious emotional, psychological and social consequences to all persons exposed to it. The subject of our research is the preconditions of digital violence in elementary schools.

\subsection{Objective and Tasks of the Research}

The aim of the research is to determine how students use digital technology, which risks they are exposed to and how they can be protected from the risk of digital violence (harassment). There is a need to analyze the current situation from the point of view of the use of modern Internet technologies by elementary schools in order to indicate the level of information literacy of students. The results of this research should serve as a basis for preventing and stopping the abuse on digital media if there are prerequisites for digital violence in elementary school, as well as raising students' awareness of the functioning and importance of digital media in the current society. The research tasks are to examine what are the most common activities of students when using a computer and a mobile phone.

\subsection{The Problem of Research}

The research should provide answers to the following questions:

- what is the degree of presence of digital violence in elementary schools;

- what is the perception of students about the safety of using the Internet;

- what is the frequency of using the Internet, as well as the ways in which today's students use modern digital devices

\subsection{The Hypothesis of the Study Reads:}

There are elements of digital violence in elementary schools.

\subsection{Sample}

The study covered 85 students, 46 boys and 39 girls, higher grades (from fifth to eighth), of which $45.9 \%$ are girls and $54.1 \%$ are boys. The survey conducted is of a survey type (Coric, 2018).

\subsection{Research Results}

The results of this research show that the use of the Internet permeates the everyday life of young people: $71.76 \%$ of the respondents are online daily, $15.29 \%$ of the students almost every day, while $8.24 \%$ of students go online once or twice a week, and $4.71 \%$ of students once or twice a month. This research should serve as a basis for preventing the abuse of digital media in elementary schools. 
Mobile phones: research conducted among elementary school students indicates the high level of use of information communication technologies, which is indicated by the fact that $95.3 \%$ of elementary school students own a mobile phone, while $4.7 \%$ do not have them, $48.2 \%$ do not send SMS messages, while $47.6 \%$ sends and receives over 10 SMS messages a day. Those students who have a mobile phone have internet access $(95.3 \%)$. Internet: if one analysis the elementary school students who use computers, then it comes to the fact that most students in the 7 th grade use the Internet daily, while no students use the Internet less than once a month. If we analyze the average of those primary users who do not use the Internet then the most common reason is that there is no need for the Internet.

The highest percentage of students started using the internet between the fourth and eighth years of age (69.2\%), while the average age at the sample level when the elementary school students started using the Internet was 7 years and three months. Compared to an average of $16.9 \%$, the principals who started using the Internet when they were over eight years old. Data from the survey show that the majority of students have a mobile phone that has access to the Internet, more precisely 81 students, while the number of students who do not have a mobile phone is only 4 students.

We have learned that it can be seen that most of the students (37) learn every day or almost every day, learn about something new, learn for the school, of which there are 7 pupils in the 5th grade, 6 students in the 6th grade, 15 pupils in the 7 th grade and 9 pupils in the 8th grade. Then, 30 pupilswatch videos, series, films 1-2 times a week onthe Internet, of which 12 students are in the 5th grade, 8 students are in the 6th grade, 6 pupils are in the 7th grade and 4 pupils are in the 8th grade. A total of 77 students visit social networks (Facebook, Instagram, Twitter, etc.), of which there are 15 students of the 5th grade, 20 students of the 6th grade, 22 students of the 7 th grade and 20 students of the 8th grade. The way of using the Internet is shown in this way.

Out of the total number of elementary school students that use computers and the Internet, 95\% have their own Facebook profiles, while 5\% do not have it. All sixth and eighth-grade students have profiles on Facebook while on the other hand, compared to the average of those students who do not have an open profile on Facebook, they are fifth-grade students and one student of the seventh grade. The highest percentage (92\%) communicates with 100 to 500 friends over the given social network, while $6 \%$ communicates with 100 to 500 friends and $2 \%$ with more than 1,000 friends. As the information most commonly found on Facebook profiles are photos (28\%), student surname (28\%) and date of birth (25\%).

In relation to the total number of primary school users who are active users of the social network Facebook 62\% said they had met the person with who they communicated via chat, while $38 \%$ did not. In the following questions on the survey, the authors want to examine whether the students did and how often in the past year do the following activities on the Internet, on which the students circled the numbers $1,2,3$, or 4 , depending on the extent to which they use a certain activity. Students were offered to round 1 if they had never done mentioned activities on the Internet in the past year, 2 if they did them once or twice in the past year, 3 if they did them 3-5 
Ljubojev, N.; Glusac, D. \& Radosav, D.: Preconditions of Digital Violence at Prima...

times in the past year, 4 if they did these things more than 5 times in the past year.The number of students who did mention activities on the internet was determined, as well as frequency. We found that the largest number of students (57) never gave personal information (name, phone number, address, email, their photo, etc.) to persons they did not know personally, 12 pupils in the 5th grade, 15 students in the 6th grade, 15 students of the 7th grade and 15 students of the 8th grade. Then, (34) students accepted friends requests more than 5 times on social networks from persons they did not know, out of which there were 3 students in the 5 th grade, 5 pupils in the 6th grade, 12 pupils in the 7th grade, and 14 students in the 8th grade. A total of 27 students have more than 3-5 times publicly (on a social network, forum, blog, etc.) commented on an acquaintance in a way that can insult them, out of which 1 student was in the 5 th grade, 1 in the 6 th grade, 15 students in the 7 th grade and 10 students in the 8th grade. Data show the frequency of various forms of risky behavior on the Internet. In addition, most respondents believe that their parents are mostly aware of how they use the Internet and that is considered by 58\% of students, while $22 \%$ think that their parents know something. On the other hand, there are $11 \%$ of those who think their parents know nothing or very little about how they use the internet.

Out of the total number of students who use computers and the Internet, 35\% say they had negative experiences when using the Internet. The most common problems they faced were: insults and rude words sent during correspondence (24.7\%), hacking profiles (3.5\%), inappropriate images and messages (7.1\%).

The direct question if they would prefer to learn more about digital communication, the risks they can be exposed to and protected from was affirmed by $60 \%$ of girls and $45 \%$ of boys. Whether they wanted to learn more about security on the Internet? The largest percentage of surveyed students wanted to find out more about safety on the Internet, and that was $96 \%$ of respondents.

The results of the research should help organize the prevention of digital violence among students in elementary schools. It is necessary to further investigate the connection between digital violence and typical forms of school violence, especially after undertaking systematic preventive measures to reduce the typical forms of peer violence.

\section{Conclusions}

The research that has been done indicates that there are prerequisites for digital violence in elementary schools. The largest number of students surveyed never disturbed other students via digital devices. However, there is no form of digital violence which none of the students interviewed took part in; more precisely, there are students who have once or more times threatened another student in each of the investigated forms of digital violence. This hypothesis is proven. This knowledge should be used when creating curriculums for information communication technology subjects as early as the elementary school level so that serious content could be implemented when it comes forming safety skills in students at the earliest elementary school age. 
Due to the more intense use of information and communication technologies, students are increasingly becoming victims of digital violence in various forms. Neglect, abuse, and violence endanger the physical, psychological and sexual integrity of the child, resulting in a violation of one of the fundamental human rights the right to life, survival, and development.

\section{References}

Baek, J., \& Bullock, L. M. (2014). Cyberbullying: A Cross-cultural perspective. Emotional and Behavioural Difficulties, Vol. 19, No. 2. pp. 226- 238.

Bauman, S.; Toomey, R.B.; Walker, J.L.(2013). Associations among bullying, cyberbullying, and suicide in highschool students. J. Adolesc. 36, pp. 341-350.

Bogavac \& Otasevic, (2015). Nacionalna studija o društvenom problemu seksualnog zlostavljanja dece. Incest trauma centar.Bogavac \& Otasevic (2015). National Study on the Social Problem of Sexual Abuse of Children. Incest Trauma Center.

Chester, K.L., Callaghan M., Cosma A., et al. (2015). Cross-national time trends in bullying victimization in 33 countries among children aged 11, 13 and 15 from 2002 to 2010. The European Journal of Public Health, Vol. 25 (suppl 2), pp. 61-64.

Coric, S., (2018). Preduslovi digitalnog nasilja u osnovnoj školi, master rad, pp. 1-40 (mentor: Radosav D). Coric, S., (2018). Preconditions of Cyberbullying at Primary School, master thesis.

Convention on the Rights of the Child. New York, 20 November 1989. United Nations, Treaty Series, Vol. 1577.

Dowell, E.; Burgess, A. \& Cavanaugh D., (2009). Clustering of Internet risk behaviors in a middle school student population. Journal of School Health, Vol. 79, No. 11, pp.547-553.

Eksploatacija dece na internetu: izveštaj o istraživanju Pokrajinskog ombudsmana, (2013). Pokrajinski ombudsman, Futura, Novi Sad. Exploitation of Children on the Internet: Research Report of the Provincial Ombudsman (2013). Provincial Ombudsman, Futura, Novi Sad.

Eslea, M.; Menesini, E.; Morita, Y.; O’Moore, M.; Mora-Merchán, J.A.; Pereira, B.; Smith, P.K. (2004). Friendship andloneliness among bullies and victims: Data from seven countries. Aggress. Behav. 30, pp.71-83.

Gasic-Pavisic, S.Z. (2004). Mere I programi za prevenciju nasilja u skoli, Zbornik Instituta za pedagoška istraživanja, 36, pp. 168-187. Gasic-Pavisic, S.Z. (2004). Interventions and programs for preventing peer violence in school. Proceedings of the Institute for Pedagogical Research, Vol. 36, pp. 168-187.

Glusac D.; R Makitan V.; Radosav D. \& Milanov D. (2015) Adolescents' informal computer usage and their expectations of ICT in teaching - Case study: Serbia, Computers \& Education, Vol. 81, pp. 133-142.

Glusac, D.; Ljubojev, N. \& Radosav, D. (2017). Parents' perception of the needs for implementing measures for child protection on the Internet, Proceedings of International Conference of Information Technology and Development ofEducation VIII (ITRO 2017), Zrenjanin, Serbia, June 22, 2017. 
Ljubojev, N.; Glusac, D. \& Radosav, D.: Preconditions of Digital Violence at Prima...

Golcevski, N. \& Milovanovic, G. (Ur.), (2004). Globalni građani - Empirijska studija korisnika Interneta u Srbiji 2003.Beograd: Beogradska otvorena škola.Golcevski, N. \&Milovanovic, G. (Ed.), (2004). Global Citizens - Empirical Study of Internet Users in Serbia 2003. Belgrade: Belgrade Open School.

Gutnick, A.L.; Robb, M.; Takeuchi, L. \& Kotler, J. (2010). Always connected: The new digital media habits of young children.New York: The Joan Ganz Cooney Center at Sesame Workshop.

Inchley, J., et al. (2016) (Eds). Growing up unequal: gender and socioeconomic differences in young people's health and wellbeing. Health Behaviour in School-aged Children (HBSC) study: international report from the 2013/2014 survey. Copenhagen, WHO Regional Office for Europe (Health Policy for Children and Adolescents, No. 7).

Kowalski, R.M.; Giumetti, G.W.; Schroeder, A.N.; Lattanner, M.R. (2014). Bullying in the digital age: A critical reviewand meta-analysis of cyberbullying research among youth.Psychological Bulletin, Vol.140, No. 4, pp.1073-1137.

Kodzopeljic J., Smederevac, S. \& Colović, P. (2010). Razlike u učestalosti i oblicima nasilnog ponašanja izmedju ucenika osnovnih i srednjih skola. Primenjena psihologija, Vol. 3, No. 4, pp. 289-305. Kodzopeljic J., Smederevac, S. \& Colović, P. (2010). Frequency and manifestations of bullying: Differences between primary and secondary school students.Applied Psychology, Vol. 3, No.4, pp. 289-305.

Kubiszewski, V., et al. (2015). Does cyberbullying overlap with school bullying when taking modality of involvement into account? Computers in Human Behavior, Vol. 43, pp. 49-57.

Livingstone S. \& Bober, (2004).

Livingston, S. \& Brake, D. (2010) On the rapid rise of social networking sites: new findings and policy implications. Children \& Society,Vol. 24, No. 1, pp. 75-83.

Livingstone, S., Haddon, L., Görzig, A. \& Ólafsson, K. (2011). Risks and Safety on the Internet: The Perspective of European Children. Full Findings. London: EU Kids Online.

Livingstone, S., et al. (Eds.) (2012). Children, Risk and Safety Online: Research and Policy Challenges in Comparative Perspective. Bristol: The Policy Press.

Livingstone, S., Stoilova, M. \& Kelly, A. (2016a) Cyberbullying: incidence, trends and consequences. In: Ending the Torment: Tackling Bullying from the Schoolyard to Cyberspace. United Nations Office of the Special Representative of the SecretaryGeneral on Violence against Children, New York, USA, pp. 115- 120. ISBN 9789211013443.

Livingstone, S., Carr, J. \& Byrne, J. (2016b). One in Three: Internet Governance and Children's Rights. Innocenti Discussion Paper No. 1, UNICEF Office of Research, Florence.

Livingstone, S. Carr J. \& Byrne, J. (2017). One in Three: Internet Governance and Children's Rights. Paper Series No 22. Waterloo, Ontario, Centre for International Governance Innovation and the Royal Institute of International Affairs, 2015.

Lenhart, A. (2015). Teen, Social Media and Technology - Overview 2015. Washington: Pew Research Center. 
Ljubojev, N., Glusac, D. \&Radosav, D. (2017). Children in the Internet: Protection and Parents' Perception, Chapter 09 in DAAAM International Scientific Book 2017, pp.105-120, B. Katalinic (Ed.), Published by DAAAM International, ISBN 978-3902734-12-9, ISSN 1726-9687, Vienna, Austria.

Ljubojev, N.,Radosav, D. Glusac, D. \&Karuovic D. (2019).Internet security and safety for students, in: Digital Environment and Education, Nadrljanski. Đ. \& Nadrljanski. M. (Eds.). Split: Redak, pp. 97- 112. ISBN 978- 953-336-533-6.

Munoz, C. \&Towner, T. (2009). Opening Facebook: how to use Facebook in the college classroom. Charleston: Society for Information Technology and Teacher Education.

Olweus, D. (2012). Cyberbullying: An overrated phenomenon? Eur. J. Dev. Psychol. 9, pp. 520-538.

Pardanjac, M.; Eleven, E. \& Kaurovic, D. (2014). Increase of User Motivation in Teaching Realized Through Distance Learning, Chapter 10 in DAAAM International Scientific Book 2014, pp.131-144, B. Katalinic (Ed.), Published by DAAAM International, ISBN 978-3-901509-98-8, ISSN 1726-9687, Vienna, Austria.

Pavlović M. \& Zunić-Pavlovic (2008). Planiranje školskih programa prevencije vršnjačkog nasilja. Nastava i vaspitanje, 57(3), 318-337. Pavlović M. \& ZunićPavlovic, (2008). Planning school programmes for preventing peer violence. Teaching and Upbringing, Vol.57, No. 3, pp. 318-337.

Pellegrini, A. D. \& Long, J. D. (2004). Part of the solution and part of the problem: The role of peers in bullying, dominance, and victimization during the transition from primary school through secondary school. In D. L. Espelage\& S. M. Swearer (Eds.), Bullying in American Schools: A social ecological perspective on prevention and intervention (pp. 107-117). Mahwah, NJ: Lawerence Erlbaum Associates, Publishers. Popadic, D. \& Kuzmanovic, D. (2013). Korišćenje digitalne tehnologije, rizici i zastupljenost digitalnog nasilja među učenicima u Srbiji, UNICEF/Institut za psihologiju Filozofskog fakulteta Univerziteta u Beogradu. Popadic, D.\& Kuzmanovic D. (2013). The Use of Digital Technology, the Risks and the Representation of Digital Violence Among Students in Serbia, UNICEF/Institute of Psychology, Faculty of Philosophy, University of Belgrade.

Popadic \& Kuzmanovic, D. (2016). Mladi u svetu interneta, Ministarstvo prosvete, UNICEF, Beograd. Popadic \& Kuzmanovic, D. (2016). Youth in the World of the Internet, Ministry of Education, UNICEF, Belgrade, ISBN 978-86-7452-066-6.

Republic Institute for Statistics - Use of Information and Communication Technologies in the Republic of Serbia, 2015.

Ruzic, N. (2011). Zaštita djece na Internetu, Nova prisutnost, Vol. 9, No. 1, pp. 155169. Ruzic, N. (2011). Protection of children on the Internet, New Presence, Vol. 9, No. 1, pp. 155-169.

Sapic J. (2016). Bezbednost dece na internetu u Srbiji: Izloženost bez koordinisane zaštite, Centar za istaživanje javnih politika. Sapic, J. (2016). Child Safety on the Internet in Serbia: Exposure without coordinated care, Center for Public Policy Research. 
Ljubojev, N.; Glusac, D. \& Radosav, D.: Preconditions of Digital Violence at Prima...

Sokolovska, V.; Dinic B. \& Marinkovic, D. (2015). Nasilništvo i viktimizacija kod učenika srednjih škola: efekti perioda ispitivanja, pola razreda i uspeha, Teme, No. 2, 2015, pp. 617-630. Sokolovska, V., Dinic B. \& Marinkovic, D. (2015). Violence and victimization in secondary school students: effects of testing period, half grade and success, Themes, No. 2, pp. 617-630.

Solberg, M.E.; Olweus, D. (2003). Prevalence estimation of school bullying with the Olweus Bully/VictimQuestionnaire. Aggress. Behav. 29, pp. 239-268.

Stevanovic, M.; Mitovski, A.; Zivkovic, D.; Strbac, N.; Zivkovic, S.; Mladenovic A. \& Vaskovic S. (2014). Internet navike dece školskog uzrasta u nekim selima borske opštine, Sinteza, Singidunum University, Beograd, pp. 354. M. Stevanovic, A. Mitovski, D. Zivkovic, N. Strbac, S. Zivkovic, A. Mladenovic, S. Vaskovic, (2014). Internet habits of school children in some villages of Bor Municipality, International Conference Synthesis, Singidunum University, Belgrade, pp. 354.

Wachs, S., Bilz, L., Fischer, S. M., \& Wright M., F. (2018). Students' Willingness to Intervene in Bullying: Direct and Indirect Associations with Classroom Cohesion and Self-Efficacy, International Journal of Environmental Research and Public Health15, 2577, pp. 1-11.

Wolak, J., Finkelhor, D., Mitchell, K. J., \& Ybarra, M. L. (2008). Online predators and their victims: Myths, realities, and implications for prevention and treatment. American Psychologist, Vol. 63, No. 2, pp. 111-128.

Wright, M.F. (2014). Longitudinal investigation of the associations between adolescents' popularity and cyber social behaviors. Journal of School Violence, Vol. 13. No. 3, pp. 291-314.

Ybarra, M.; Mitchell, K.; Finkelhor, D. \& Wolak, J. (2007). Internet prevention messages - targeting the right online behaviors. Archives of Pediatrics \& Adolescent Medicine, Vol.161, No. 2, pp. 138-145.

Zukovic, S. \& Slijepcevic, S. (2015). Roditeljska kontrola ponašanja dece na internetu i socijalnim mrežama, Nastava i vaspitanje, br. 2. pp. 239-254. Zukovic, S. Slijapcevic, S. (2015). Parental control the behavior of children on the Internet and social networks, Teaching and Upbringing, Vol. 64, No. 2, pp. 239-254.

*** http://www.ncpc.org/newsroom/current-campaigns/Cyberbullying, National Crime Prevention Council, Accesed on: 2018.12.20

*** UNICEF, The State of the World's Children 2017: Children in the Digital World, https://www.unicef.org/publications/files/SOWC_2017_ENG_WEB.pdf. Accesed on: 2018.12.20. 